NIST Technical Note 2024

\title{
Commissioning ASHRAE High- Performance Sequences of Operation for Multiple-Zone Variable Air Volume Air Handling Units
}

Natascha Milesi Ferretti Michael A. Galler Steven T. Bushby

Justin Sorra 
NIST Technical Note 2024

\title{
Commissioning ASHRAE High- Performance Sequences of Operation for Multiple-Zone Variable Air Volume Air Handling Units
}

\author{
Natascha Milesi Ferretti, P.E. \\ Michael A. Galler \\ Steven T. Bushby \\ Energy and Environment Division \\ Engineering Laboratory \\ Justin Sorra \\ University of Maryland \\ NIST Associate
}

This publication is available free of charge from:

https://doi.org/10.6028/NIST.TN.2024

February 2019

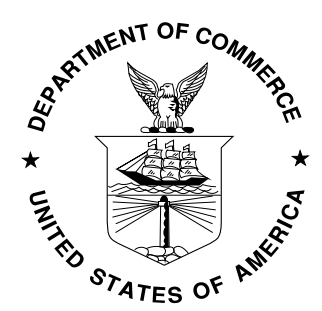

U.S. Department of Commerce Wilbur L. Ross, Jr., Secretary

National Institute of Standards and Technology Walter Copan, NIST Director and Undersecretary of Commerce for Standards and Technology 
Certain commercial entities, equipment, or materials may be identified in this document in order to describe an experimental procedure or concept adequately. Such identification is not intended to imply recommendation or endorsement by the National Institute of Standards and Technology, nor is it intended to imply that the entities, materials, or equipment are necessarily the best available for the purpose.

National Institute of Standards and Technology Technical Note 2024

Natl. Inst. Stand. Technol. Tech. Note 2024, 30 pages (February 2019) CODEN: NTNOEF

This publication is available free of charge from:

https://doi.org/10.6028/NIST.TN.2024 


\begin{abstract}
ASHRAE Guideline 36 High Performance Sequences of Operation for HVAC Systems was developed to provide a reference set of high-performance control sequences for air-side heating, ventilating and air-conditioning (HVAC) equipment, including multiple-zone variable-air-volume (VAV) air handlers and associated terminal equipment. The intent is that high-performance buildings will perform better if well-known sequences of operation are specified and controls contractors refine their products to correctly implement them. In this work functional performance tests for the Guideline 36 sequences were developed and implemented using the HVAC-Cx commissioning tool. The HVAC-Cx Functional Performance Test Module was used to commission an implementation of Guideline 36 sequences in the NIST Virtual Cybernetic Building Testbed. The functional performance tests are described and the effectiveness of using the HVAC-Cx tool for detecting faults and implementation errors is evaluated.
\end{abstract}

\title{
Key words
}

ASHRAE Guideline 36; BACnet; commissioning; functional performance tests; HVAC; HVAC-Cx; sequence of operations 


\section{Table of Contents}

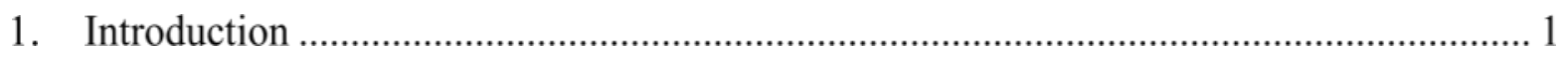

2. HVAC-Cx and the Functional Performance Test Module ……........................................ 1

3. Guideline 36 Sequences of Operation and Fault Detection Rules..................................... 2

3.1. Trim \& Respond Logic.................................................................................... 2

3.2. Automatic Fault Detection and Diagnostics (AFDD) ……….................................... 3

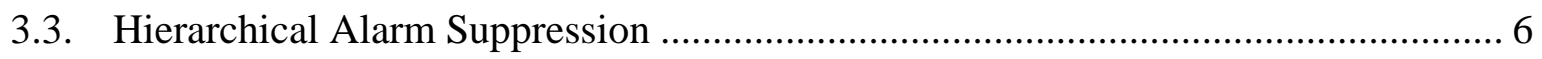

3.4. Validation with Real Control Hardware............................................................. 6

3.5. Educational Features to Improve User Understanding and Reduce Cost .................... 6

4. Testing a Library of Functional Performance Tests .......................................................... 7

4.1. Experimental Procedure ………………………………........................................ 7

4.2. Use Case \#1: Supply Air Temperature Control Test for VAV AHUs ......................... 8

4.3. Use Case \#2: Trim \& Respond Static Pressure Reset Logic for VAV AHUs ............ 8

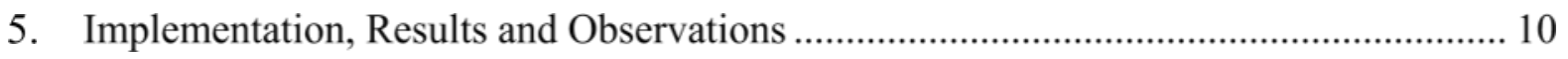

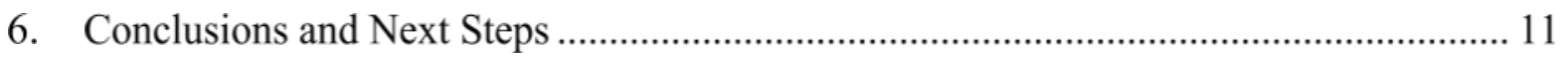

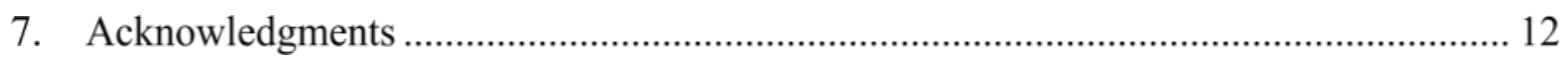

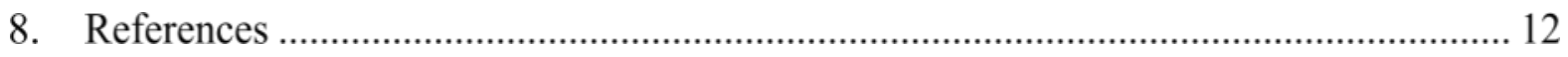

Appendix A: Multiple Zone VAV AHU Test Scripts for Normal Operation........................... 13

Appendix B: Multiple Zone VAV AHU Test Scripts for Fault Conditions ............................ 14

Appendix C: Use Case \#1 Supply Air Temperature Control Test for VAV AHUs Event

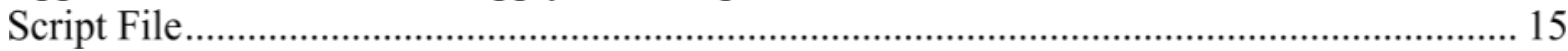

Appendix D: Use Case \#2 Trim \& Respond Static Pressure Reset Logic for VAV AHUs Event Script File 


\section{Introduction}

The building industry recognizes a need to improve the performance and reliability of heating, ventilating, and air-conditioning (HVAC) equipment and controls, and to reduce the burden of commissioning (Cx) these systems to support their performance. Significant barriers include:

- the lack of industry standards for control systems logic;

- the common practice of introducing custom logic for each application;

- that systems often are not fully debugged and free of operational problems, due to the cost of programming and $\mathrm{Cx}$;

- and that poorly documented control sequences reduce the likelihood that the implementation will meet design intent $[1,2]$.

In 2018 ASHRAE published Guideline 36 "High Performance Sequences of Operation for HVAC Systems" [3]. It provides a reference set of high-performance control sequences for airside HVAC equipment including multiple-zone variable-air-volume (VAV) air handlers and associated terminal equipment. The intent is that high-performance buildings will perform better if well-known sequences of operation are specified and controls contractors refine their products to correctly implement them.

ASHRAE Guideline 36 contains reference sequences that were derived from the results of ASHRAE sponsored Research Project 1455 (RP-1455) [4]. Guideline 36 also includes some real-time automated fault detection and diagnostics capabilities based on air-handling unit performance assessment rules developed at the National Institute of Standards and Technology [5]. Additional research is underway to expand the guidance to include sequences for water-side systems [6].

After implementing and adapting the reference control sequences for specific applications, it is necessary to ensure that the HVAC components and systems are working together and that their integrated performance meets the owner's project requirements. Functional performance testing is the process of verifying the correct operation of HVAC equipment and the associated control logic by testing their combined functionality in different modes of operation $[7,8]$. In functional performance tests (FPTs) for operation monitoring, the ambient conditions and normal setpoint values are used. In active FPTs, the values of inputs and setpoints may be changed to force the system into a mode required for testing. This approach can be used to accelerate verification of operation over a wide variety of normally occurring operating conditions.

In this work, FPTs were developed to evaluate compliance with Guideline 36 sequences of operation and fault detection capabilities. The building Cx software tool HVAC-Cx [9] was used to automate the tests, and the RP-1455 control logic [4] implemented in the NIST Virtual Cybernetic Building Testbed (VCBT) [10] was used as a test building.

\section{HVAC-Cx and the Functional Performance Test Module}

HVAC-Cx [9] is a semi-automated building Cx software tool used to facilitate the testing and analysis of HVAC systems. It enables the commissioning agent or building operator to monitor the performance of the air-handling units (AHUs), chiller loops, and terminal units in one building or multiple buildings. Testing can be carried out by ongoing monitoring of system 
operation or through active intervention to force the system into desired modes of operation. HVAC-Cx helps the user to detect performance faults using archival data, reporting the following information to the user for further diagnostic assistance; when a rule condition has been met, a fault has been detected and suggestions for the cause of the fault are presented. HVAC-Cx can quickly analyze data collected over a long period of time and can be used to analyze data collected before the Cx process began. HVAC-Cx has been used to perform active commissioning in a performing arts center, where the FPTs were custom made for the six AHUs [11]. The PC-based program was developed by NIST and is available for free download [12].

The Functional Performance Test Module (FPTM) is a module of HVAC-Cx that performs live tests using real-time data, by communicating directly with the HVAC system using the BACnet protocol. The FPTM can perform operation monitoring by reading data from the system, and it can also initiate active testing by writing values to the system. Both types of testing are performed by using customizable test scripts, reading data or commanding the system into a different mode of operation, and then applying expert rules that can detect improper system operation [9].

The extent of the HVAC system performance assessment is generally limited by the availability of design data (e.g., control requirements and sequencing strategy), and basic system metrics such as operational data (e.g., occupancy information, setpoint values, sensor measurements, and control signals). Typical commercial grade sensors installed for control purposes have sufficient accuracy to conduct such assessments; laboratory grade instruments are not required.

The FPTM test scenarios can be created by the user or selected from a reference library. Data is collected during the test sequence, which can be saved to a file for later analysis. By implementing standard sequences of operation, the control requirements and sequencing strategy are well-defined, and tools to evaluate the functional performance of any implementation can be standardized.

\section{Guideline 36 Sequences of Operation and Fault Detection Rules}

The Guideline 36 high performance sequences are best practice approaches for controlling common equipment configurations. The sequences are designed to provide multiple benefits, including reducing energy consumption, improving indoor air quality, and reducing the time required to design, program, and commission HVAC systems. The guideline includes general logic (e.g., zone groups, zone mode, and alarms), terminal units, and both single-zone and multiple-zone VAV AHUs.

The control sequences have several innovative features, including: trim \& respond logic, automated fault detection and diagnostics, hierarchical alarm suppression, validation with real control hardware, and educational features to improve user understanding.

\subsection{Trim \& Respond Logic}

One element of the control sequences is the Trim \& Respond (T\&R) reset strategy that is applied for control of the static air pressure and air temperature setpoints. It utilizes a request system from each zone to adjust the static air pressure or supply air temperature. For example, in heating mode with no significant zone requests, the setpoint is reduced at a specified rate 
every two minutes. This is the trim phase, during which the setpoint steadily decreases. If a zone is not able to meet its setpoint, it generates a request. If the conditions move far enough from the setpoint, a second or third request will be generated. Important zones may also get a multiplier on their requests. When a sufficient number of requests are generated from all zones, the setpoint is increased at a specified rate until the number of requests is decreased below the threshold. This is the respond phase, as the setpoint increases to meet the zone demand. T\&R logic is particularly beneficial for multiple-zone AHUs, because each zone can be weighted differently to prioritize critical zones or ignore others.

\subsection{Automatic Fault Detection and Diagnostics (AFDD)}

AFDD is a diagnostic approach that continuously uses sensor inputs to evaluate AHU performance and function under a given set of conditions. Because they rely on sensor inputs, some conditions may be ignored if the system does not contain the corresponding sensors. A summary of the fifteen fault conditions (FC) considered in Guideline 36 is shown in Table 1. Although the basis for the AFDD was validated in both simulation and field studies [6], the FCs were not validated in RP-1455. This highlights the need for Cx to identify functional issues that may arise under different operating conditions. . Each FC is presented with information in three rows. For example, in FC\#1, the top row that is labeled Equation, lists the two conditions that are evaluated. The middle row that is labeled Description describes the condition that occurs when the equation is true. The bottom row that is labeled Fault Simulation Method describes the approach used in the HVAC-Cx test script to establish the fault condition that the AFDD is designed to detect. HVAC-Cx test scripts that implement the FPTs shown in Table 1 may be downloaded from the HVAC-Cx web page [12]. The last column in Table 1 presents the applicable operating state (OS) for the fault condition. These operating states are presented in Table 2.

The following list defines the abbreviations used in the equations that establish the fault conditions. A complete description of the variables in each equation can be found in Table 5.16.14.5 of ASHRAE Guideline 36 [3].

1. SAT = supply air temperature

2. MAT $=$ mixed air temperature

3. RAT = return air temperature

4. OAT $=$ outdoor air temperature

5. $\mathrm{DSP}=$ duct static pressure

6. $\mathrm{HC}=$ heating coil valve setting

7. $\mathrm{HCLT}_{\mathrm{AVG}}=$ heating coil leaving temp.
8. DSPSP $=$ duct static pressure setpoint

9. SATSP = supply air temperature setpoint 10. VFDSPD = variable frequency drive speed

11. $\varepsilon_{(\mathrm{VAR})}=$ error tolerance for a variable

12. $\Delta=$ change in value

13. $\triangle \mathrm{TSF}=$ temp rise across supply fan

14. $\mathrm{CCET}_{\mathrm{AVG}}=$ cooling coil entering temperature

Table 1: Summary of Fault Conditions (Adapted from Guideline 36 [3])

\begin{tabular}{|c|c|c|c|}
\hline \multirow{3}{*}{ FC\#1 } & Equation & DSP $<$ DSPSP $-\varepsilon_{\text {DSP }}$ and VFDSPD $\geq 99 \%-\varepsilon_{\text {VFDSPD }}$ & \multirow{3}{*}{$\begin{array}{c}\text { Applies to } \\
\text { OS } \\
\# 1-\# 5\end{array}$} \\
\hline & Description & Duct static pressure is too low with fan at full speed. & \\
\hline & $\begin{array}{l}\text { Fault } \\
\text { Simulation } \\
\text { Method }\end{array}$ & $\begin{array}{l}\text { Lowering the DSP below the setpoint by } 77 \mathrm{~Pa} \\
\left(0.31 \mathrm{inH}_{2} \mathrm{O}\right) \text { and setting the supply fan to } 100 \% \text { speed. }\end{array}$ & \\
\hline
\end{tabular}




\begin{tabular}{|c|c|c|c|}
\hline \multirow{3}{*}{$\begin{array}{l}\text { FC\#2 } \\
\text { (omit if no } \\
\text { MAT } \\
\text { sensor) }\end{array}$} & Equation & $\begin{aligned} \mathrm{MAT}_{\mathrm{AVG}}+ & \varepsilon_{\mathrm{MAT}}<\min \left[\left(\mathrm{RAT}_{\mathrm{AVG}}-\varepsilon_{\mathrm{RAT}}\right)\right. \\
& \left.\left(\mathrm{OAT}_{\mathrm{AVG}}-\varepsilon_{\mathrm{OAT}}\right)\right]\end{aligned}$ & \multirow{3}{*}{$\begin{array}{l}\text { Applies to } \\
\text { OS } \\
\# 1-\# 5\end{array}$} \\
\hline & Description & MAT too low; should be between OAT and RAT. & \\
\hline & $\begin{array}{c}\text { Fault } \\
\text { Simulation } \\
\text { Method } \\
\end{array}$ & $\begin{array}{l}\text { Setting MAT } 8.3^{\circ} \mathrm{C}\left(15^{\circ} \mathrm{F}\right) \text { lower than RAT, given } \\
\text { OAT > RAT. }\end{array}$ & \\
\hline \multirow{3}{*}{$\begin{array}{l}\text { FC\#3 } \\
\text { (omit if no } \\
\text { MAT } \\
\text { sensor) }\end{array}$} & Equation & $\begin{array}{c}\mathrm{MAT}_{\mathrm{AVG}}-\varepsilon_{\mathrm{MAT}}>\max \left[\left(\mathrm{RAT}_{\mathrm{AVG}}+\varepsilon_{\mathrm{RAT})}\right.\right. \\
\left.\left(\mathrm{OAT}_{\mathrm{AVG}}+\varepsilon_{\mathrm{OAT}}\right)\right]\end{array}$ & \multirow{3}{*}{$\begin{array}{l}\text { Applies to } \\
\text { OS } \\
\# 1-\# 5\end{array}$} \\
\hline & Description & MAT too high; should be between OAT and RAT. & \\
\hline & $\begin{array}{c}\text { Fault } \\
\text { Simulation } \\
\text { Method } \\
\end{array}$ & $\begin{array}{l}\text { Setting MAT } 8.3^{\circ} \mathrm{C}\left(15^{\circ} \mathrm{F}\right) \text { higher than OAT, given } \\
\text { OAT > RAT. }\end{array}$ & \\
\hline \multirow[b]{3}{*}{ FC\#4 } & Equation & $\Delta \mathrm{OS}>\Delta \mathrm{OS}_{\mathrm{MAX}}$ & \multirow[b]{3}{*}{$\begin{array}{l}\text { Applies to } \\
\text { OS } \\
\# 1-\# 5\end{array}$} \\
\hline & Description & Too many changes in Operating State. & \\
\hline & $\begin{array}{l}\text { Fault } \\
\text { Simulation } \\
\text { Method }\end{array}$ & $\begin{array}{l}\text { Opening cooling coil, closing heating coil, and modulating } \\
\text { OA damper between minimum value and } 100 \% \text { to } \\
\text { simulate changes between mechanical + economizer } \\
\text { cooling mode and mechanical cooling mode eight times } \\
\text { within an hour. }\end{array}$ & \\
\hline \multirow{3}{*}{$\begin{array}{l}\text { FC\#5 } \\
\text { (omit if no } \\
\text { MAT } \\
\text { sensor) }\end{array}$} & Equation & $\mathrm{SAT}_{\mathrm{AVG}}+\varepsilon_{\mathrm{SAT}} \leq \mathrm{MAT}_{\mathrm{AVG}}-\varepsilon_{\mathrm{MAT}}+\Delta \mathrm{TSF}_{\mathrm{SF}}$ & \multirow{3}{*}{$\begin{array}{l}\text { Applies to } \\
\text { OS \#1 }\end{array}$} \\
\hline & Description & SAT too low; should be higher than MAT. & \\
\hline & $\begin{array}{l}\text { Fault } \\
\text { Simulation } \\
\text { Method }\end{array}$ & $\begin{array}{l}\text { Setting MAT to } 21.1^{\circ} \mathrm{C}\left(70^{\circ} \mathrm{F}\right) \text { and SAT to } 12.7^{\circ} \mathrm{C} \\
\left(55^{\circ} \mathrm{F}\right) \text { while in heating mode. }\end{array}$ & \\
\hline \multirow{3}{*}{ FC\#6 } & Equation & $\begin{array}{c}\left|\mathrm{RAT}_{\mathrm{AVG}}-\mathrm{OAT}_{\mathrm{AVG}}\right| \geq \Delta \mathrm{T}_{\mathrm{MIN}} \\
\stackrel{\text { and }}{\left|\% \mathrm{OA}-\% \mathrm{OA}_{\mathrm{MIN}}\right|>\varepsilon_{\mathrm{F}}}\end{array}$ & \multirow{3}{*}{$\begin{array}{l}\text { Applies to } \\
\text { OS } \\
\# 1 \text {, \#4 }\end{array}$} \\
\hline & Description & OA fraction is too low or too high; should equal $\% \mathrm{OA}_{\mathrm{MIN}}$. & \\
\hline & $\begin{array}{l}\text { Fault } \\
\text { Simulation } \\
\text { Method }\end{array}$ & $\begin{array}{l}\text { Setting MAT very close to the OAT, so the OA fraction } \\
\text { was approximately } 1 .\end{array}$ & \\
\hline \multirow{3}{*}{ FC\#7 } & Equation & $\begin{array}{c}\mathrm{SAT}_{\mathrm{AVG}}<\mathrm{SATSP}-\varepsilon_{\mathrm{SAT}} \\
\text { and } \\
\mathrm{HC} \geq 99 \%\end{array}$ & \multirow{3}{*}{$\begin{array}{l}\text { Applies to } \\
\text { OS \#1 }\end{array}$} \\
\hline & Description & SAT too low in full heating. & \\
\hline & $\begin{array}{l}\text { Fault } \\
\text { Simulation } \\
\text { Method }\end{array}$ & $\begin{array}{l}\text { Setting SAT } 8.3^{\circ} \mathrm{C}\left(15^{\circ} \mathrm{F}\right) \text { lower than SAT setpoint while } \\
\text { in heating mode and ensuring heating coil fully open. }\end{array}$ & \\
\hline
\end{tabular}




\begin{tabular}{|c|c|c|c|}
\hline \multirow{3}{*}{$\begin{array}{l}\text { FC\#8 } \\
\text { (omit if no } \\
\text { MAT } \\
\text { sensor) }\end{array}$} & Equation & $\mid$ SATAVG $_{\text {ASF }}-\mathrm{TATAVG}_{\mathrm{A}} \mid>\sqrt{\varepsilon_{\mathrm{SAT}}{ }^{2}+\varepsilon_{\mathrm{MAT}}{ }^{2}}$ & \multirow{3}{*}{$\begin{array}{l}\text { Applies to } \\
\text { OS \#2 }\end{array}$} \\
\hline & Description & SAT and MAT should be approximately equal. & \\
\hline & $\begin{array}{l}\text { Fault } \\
\text { Simulation } \\
\text { Method }\end{array}$ & $\begin{array}{l}\text { Setting MAT } 5.6^{\circ} \mathrm{C}\left(10^{\circ} \mathrm{F}\right) \text { higher than SAT while in free } \\
\text { cooling mode. }\end{array}$ & \\
\hline \multirow{3}{*}{ FC\#9 } & Equation & $\mathrm{OAT}_{\mathrm{AVG}}-\varepsilon_{\mathrm{OAT}}>\mathrm{SATSP}-\Delta \mathrm{T}_{\mathrm{SF}}+\varepsilon_{\mathrm{SAT}}$ & \multirow{3}{*}{$\begin{array}{l}\text { Applies to } \\
\text { OS \#2 }\end{array}$} \\
\hline & Description & $\begin{array}{l}\text { OAT is too high for free cooling without additional } \\
\text { mechanical cooling. }\end{array}$ & \\
\hline & $\begin{array}{l}\text { Fault } \\
\text { Simulation } \\
\text { Method }\end{array}$ & $\begin{array}{l}\text { Setting SATSP } 8.3^{\circ} \mathrm{C}\left(15^{\circ} \mathrm{F}\right) \text { lower than OAT while in } \\
\text { free cooling mode. }\end{array}$ & \\
\hline \multirow{3}{*}{$\begin{array}{l}\text { FC\#10 } \\
\text { (omit if no } \\
\text { MAT } \\
\text { sensor) }\end{array}$} & Equation & $\mid$ MATAVG $_{A}-$ OATAVG $_{A} \mid>\sqrt{\varepsilon_{\text {MAT }^{2}}+\varepsilon_{O A T}{ }^{2}}$ & \multirow{3}{*}{$\begin{array}{l}\text { Applies to } \\
\text { OS \#3 }\end{array}$} \\
\hline & Description & OAT and MAT should be approximately equal. & \\
\hline & $\begin{array}{c}\text { Fault } \\
\text { Simulation } \\
\text { Method }\end{array}$ & $\begin{array}{l}\text { Setting MAT } 8.3^{\circ} \mathrm{C}\left(15^{\circ} \mathrm{F}\right) \text { lower than OAT while in } \\
\text { mechanical + economizer cooling mode. }\end{array}$ & \\
\hline \multirow{3}{*}{ FC\#11 } & Equation & $\mathrm{OAT}_{\mathrm{AVG}}+\varepsilon_{\mathrm{OAT}}<\mathrm{SATSP}-\Delta \mathrm{T}_{\mathrm{SF}}-\varepsilon_{\mathrm{SAT}}$ & \multirow{3}{*}{$\begin{array}{l}\text { Applies to } \\
\text { OS \#3 }\end{array}$} \\
\hline & Description & OAT is too low for $100 \%$ OA cooling. & \\
\hline & $\begin{array}{c}\text { Fault } \\
\text { Simulation } \\
\text { Method }\end{array}$ & $\begin{array}{l}\text { Setting SATSP } 8.3^{\circ} \mathrm{C}\left(15^{\circ} \mathrm{F}\right) \text { higher than OAT while in } \\
\text { mechanical + economizer cooling mode. }\end{array}$ & \\
\hline \multirow{3}{*}{$\begin{array}{l}\text { FC\#12 } \\
\text { (omit if no } \\
\text { MAT } \\
\text { sensor) }\end{array}$} & Equation & $\mathrm{SAT}_{\mathrm{AVG}}-\varepsilon_{\mathrm{SAT}}-\Delta \mathrm{T}_{\mathrm{SF}} \geq \mathrm{MATAVG}+\varepsilon_{\mathrm{MAT}}$ & \multirow{3}{*}{$\begin{array}{l}\text { Applies to } \\
\text { OS } \\
\# 3, \# 4\end{array}$} \\
\hline & Description & SAT too high; should be less than MAT. & \\
\hline & $\begin{array}{l}\text { Fault } \\
\text { Simulation } \\
\text { Method }\end{array}$ & $\begin{array}{l}\text { Setting SAT } 5.6^{\circ} \mathrm{C}\left(10^{\circ} \mathrm{F}\right) \text { higher than MAT while in } \\
\text { mechanical + economizer cooling or mechanical cooling } \\
\text { with minimum outdoor air modes. }\end{array}$ & \\
\hline \multirow{3}{*}{ FC\#13 } & Equation & $\mathrm{SAT}_{\mathrm{AVG}}>\mathrm{SATSP}+\varepsilon_{\mathrm{SAT}}$ and $\mathrm{CC} \geq 99 \%$ & \multirow{3}{*}{$\begin{array}{l}\text { Applies to } \\
\text { OS } \\
\# 3, \# 4\end{array}$} \\
\hline & Description & SAT too high in full cooling. & \\
\hline & $\begin{array}{l}\text { Fault } \\
\text { Simulation } \\
\text { Method }\end{array}$ & $\begin{array}{l}\text { Setting SAT } 2.8^{\circ} \mathrm{C}\left(5^{\circ} \mathrm{F}\right) \text { greater than SATSP while in } \\
\text { mechanical + economizer cooling or mechanical cooling } \\
\text { with minimum outdoor air modes. }\end{array}$ & \\
\hline \multirow{3}{*}{ FC\#14 } & Equation & $\begin{array}{l}\text { CCETAVG }-\mathrm{CCLTAVG}_{\mathrm{AV}} \geq \sqrt{\varepsilon_{\mathrm{CCET}^{2}}{ }^{2} \varepsilon_{\mathrm{CCLT}}^{2}}+\Delta \mathrm{TsF}^{*} \\
* \text { Fan heat factor included or not depending on location of } \\
\text { sensors used for CCET and CCLT }\end{array}$ & \multirow{3}{*}{$\begin{array}{l}\text { Applies to } \\
\text { OS } \\
\# 1, \# 2\end{array}$} \\
\hline & Description & Temperature drop across inactive cooling coil. & \\
\hline & $\begin{array}{l}\text { Fault } \\
\text { Simulation } \\
\text { Method }\end{array}$ & $\begin{array}{l}\text { Setting cooling coil leaving temperature (or closest } \\
\text { downstream temperature) } 8.3^{\circ} \mathrm{C}\left(10^{\circ} \mathrm{F}\right) \text { less than cooling } \\
\text { coil entering temperature (or closest upstream } \\
\text { temperature). }\end{array}$ & \\
\hline
\end{tabular}




\begin{tabular}{|c|c|c|c|}
\hline \multirow{3}{*}{ FC\#15 } & Equation & $\begin{array}{l}\text { HCLTAVG }- \text { HCETAVG } \geq \sqrt{\varepsilon_{\text {HCET }^{2}}+\varepsilon_{\text {HCLT }}^{2}}+\Delta \mathrm{TSF}^{*} \\
\text { *Fan heat factor included or not depending on location of } \\
\text { sensors used for HCET and HCLT }\end{array}$ & \multirow{3}{*}{$\begin{array}{l}\text { Applies to } \\
\text { OS } \\
\# 2-\# 4\end{array}$} \\
\hline & Description & Temperature rise across inactive heating coil. & \\
\hline & $\begin{array}{l}\text { Fault } \\
\text { Simulation } \\
\text { Method }\end{array}$ & $\begin{array}{l}\text { Setting heating coil entering temperature (or closest } \\
\text { upstream temperature) } 5.6^{\circ} \mathrm{C}\left(10^{\circ} \mathrm{F}\right) \text { less than heating coil } \\
\text { leaving temperature (or closest downstream temperature). }\end{array}$ & \\
\hline
\end{tabular}

Table 2: Operating States for Multiple Zone VAV AHUs (Adapted from Guideline 36 [3])

\begin{tabular}{|l|l|}
\hline Operating State & \multicolumn{1}{c|}{ Description } \\
\hline OS\#1 & Heating \\
\hline OS\#2 & Free Cooling, Modulating Outdoor Air Damper \\
\hline OS\#3 & Mechanical + Economizer Cooling \\
\hline OS\#4 & Mechanical Cooling, Minimum Outdoor Air Damper \\
\hline OS\#5 & Unknown or Dehumidification \\
\hline
\end{tabular}

In addition to providing fault detection, each fault condition identifies one or more possible diagnosis that can aid the user in determining the cause of the fault. For example, for FC\#1, possible diagnoses include problem with variable frequency drive, mechanical problem with fan, fan undersized and SAT setpoint too high (too much zone demand).

\subsection{Hierarchical Alarm Suppression}

The control sequences are designed such that if an upstream source is in alarm, the downstream alarms are suppressed. For example, in the case of reheat for a VAV terminal box, there are three control inputs: static pressure, inlet air temperature, and reheat type (electric or hot water). If the AHU fan trips off, zone temperature alarms are suppressed to help the operator focus on the cause of the fault to avoid alarm overload. Although this element was not a requirement in RP-1455, it was included in the control sequences used for this research. The RP-1455 implementation matches the requirements of Guideline 36.

\subsection{Validation with Real Control Hardware}

Guideline 36 control algorithms have been validated as a part of ASHRAE sponsored Research Project 1455 (RP-1455) [4]. This project included programming the control sequences and testing them in a simulation and in real control hardware [1].

\subsection{Educational Features to Improve User Understanding and Reduce Cost}

One challenge in establishing high performance sequences of operation is writing the sequences in a way that improves user understanding so that different implementations of the control sequences, across varying software platforms, result in the same functional performance. The authors of Guideline 36 use unambiguous English-language written sequences and provide functional logic block representations. To further improve understanding, the sequences include embedded application notes and examples. The intent of these features is to guide users to develop sequences providing the best performance to improve 
energy efficiency and consistency of implementation, while reducing the effort and costs associated with writing, programming and validating control sequences.

\section{Testing a Library of Functional Performance Tests}

When evaluating an HVAC system, the FPTs should ideally cover all modes of operation: occupied, unoccupied, warm-up, cool-down, and emergency modes, including safety trip, fire, and smoke modes. The FPT Library provides a resource to commissioning agents and building operators with expert knowledge of the systems, enabling more complete and consistent testing for a given level of effort by automating portions of the commissioning process.

The FPTs mostly address the performance of the AHU overall, but also provide basic checks at the component and sensor levels. Pre-functional checks of the ancillary equipment such as dampers and actuators are to be carried out as a prerequisite to carrying out FPTs for the full HVAC systems and components. Test scripts are employed to facilitate pre-functional checks when possible. General trending evaluation, such as trending damper control over a 1 to 2 day period with a 2-minute interval, is carried out independently of the FPTM.

As an initial effort, an implementation of the standard sequences of operation for multiplezone VAV AHUs were selected for developing a library of functional performance tests (FPTs) for ongoing commissioning. Table 3 lists the system or component being evaluated and the mode of operation, along with a listing of the FPTs. Therefore, the FPTs developed for the first application are broadly valid for other AHUs. The FPTs may be downloaded from the HVAC-Cx web page [12].

\subsection{Experimental Procedure}

A subset of the functional performance test scripts available from HVAC-Cx was selected for testing. The tests were performed using the Virtual Cybernetic Building Testbed (VCBT) [10], which combines real building controllers with detailed computer models of buildings. The VCBT allows tests to be run in heating, cooling, or swing season as required. It also allows repeated testing with the same outdoor weather data. For these tests, the VCBT computer models were configured to simulate a small office building with six zones and a multiple zone VAV AHU system. The appropriate configuration files provided from RP-1455 were uploaded

Table 3: List of Developed Test Scripts

\begin{tabular}{|l|l|}
\hline \multicolumn{1}{|c|}{ Equipment/Mode } & \multicolumn{1}{|c|}{ Functional Performance Test } \\
\hline Multiple Zone VAV AHU/Occupied Mode & Zone Air Temperature Reset Test \\
\cline { 2 - 2 } & Supply Air Temperature Control Test \\
\cline { 2 - 2 } & Trim \& Respond Parameter Test \\
\cline { 2 - 2 } & Trim \& Respond Temperature Test \\
\cline { 2 - 2 } & Trim \& Respond Static Pressure Test \\
\cline { 2 - 2 } Multiple Zone VAV AHU/Other Mode & Sum of Zones Airflow Test \\
\cline { 2 - 2 } & Off Mode Response Test \\
\hline Setback Mode Test \\
\hline Multiple Zone VAV AHU/Safety Shutdown & Setup Mode Test \\
\hline
\end{tabular}


to the HVAC controllers and adapted to match the simulated building. The tests were run while the simulated building was in occupied mode.

\subsection{Use Case \#1: Supply Air Temperature Control Test for VAV AHUs}

This test case confirmed the AHU response to changes in supply air temperature setpoint. The changes in setpoint were segmented twenty minutes apart to give adequate time for the AHU to adjust the supply air temperature. A summary of the results is shown in Table 4. Bold text indicates write events. For more details, the event script and log file are available in Appendix C.

Table 4: FPTM Results of the Supply Air Temperature Control Test

\begin{tabular}{|c|c|c|}
\hline Event Description & $\begin{array}{c}\text { Time Differential } \\
\text { from Start } \\
\text { (Minutes) }\end{array}$ & FPTM Value \\
\hline Read SAT & +0 & $18.7^{\circ} \mathrm{C}\left(65.6^{\circ} \mathrm{F}\right)$ \\
\hline Read and store SAT setpoint & +0 & $18.33^{\circ} \mathrm{C}\left(65^{\circ} \mathrm{F}\right)$ \\
\hline Raise setpoint $3^{\circ} \mathrm{C}\left(5^{\circ} \mathrm{F}\right)$ & +0 & $21.1^{\circ} \mathrm{C}\left(7^{\circ}{ }^{\circ} \mathrm{F}\right)$ \\
\hline Read and verify SAT response & +20 & $20.9^{\circ} \mathrm{C}\left(69.6^{\circ} \mathrm{F}\right)$ \\
\hline Raise setpoint $3^{\circ} \mathrm{C}\left(5^{\circ} \mathrm{F}\right)$ & +20 & $23.9^{\circ} \mathrm{C}\left(75^{\circ} \mathrm{F}\right)$ \\
\hline Read and verify SAT response & +40 & $23.8^{\circ} \mathrm{C}\left(74.8^{\circ} \mathrm{F}\right)$ \\
\hline Raise setpoint $3^{\circ} \mathrm{C}\left(5^{\circ} \mathrm{F}\right)$ & +40 & $26.7^{\circ} \mathrm{C}\left(80^{\circ} \mathrm{F}\right)$ \\
\hline Read and verify SAT response & +60 & $26.3^{\circ} \mathrm{C}\left(79.4^{\circ} \mathrm{F}\right)$ \\
\hline Lower setpoint $3^{\circ} \mathrm{C}\left(5^{\circ} \mathrm{F}\right)$ & +60 & $23.9^{\circ} \mathrm{C}\left(75^{\circ} \mathrm{F}\right)$ \\
\hline Read and verify SAT response & +80 & $23.8^{\circ} \mathrm{C}\left(74.9^{\circ} \mathrm{F}\right)$ \\
\hline Lower setpoint $3^{\circ} \mathrm{C}\left(5^{\circ} \mathrm{F}\right)$ & +80 & $21.1^{\circ} \mathrm{C}\left(7^{\circ}{ }^{\circ} \mathrm{F}\right)$ \\
\hline Read and verify SAT response & +100 & $21^{\circ} \mathrm{C}\left(69.8^{\circ} \mathrm{F}\right)$ \\
\hline Lower setpoint $3^{\circ} \mathrm{C}\left(5^{\circ} \mathrm{F}\right)$ & +100 & $18.3^{\circ} \mathrm{C}\left(65^{\circ} \mathrm{F}\right)$ \\
\hline Read and verify SAT response & +120 & $18.2^{\circ} \mathrm{C}\left(64.8^{\circ} \mathrm{F}\right)$ \\
\hline
\end{tabular}

This test case increased the setpoint value by $2.8^{\circ} \mathrm{C}\left(5^{\circ} \mathrm{F}\right)$ every twenty minutes for three iterations and verified the supply air temperature response. The setpoint was then reduced by $2.8^{\circ} \mathrm{C}\left(5^{\circ} \mathrm{F}\right)$ every twenty minutes for three iterations. Again, the supply air temperature was read to confirm the intended decrease.

\subsection{Use Case \#2: Trim \& Respond Static Pressure Reset Logic for VAV AHUs}

The second test case portrays the trim \& respond logic using VAV box air requests to observe the AHU airflow setpoint response. A summary of the results is shown in Table 5. Bold text indicates write events. For more details, the event script and log file can be accessed in Appendix D. 
Table 5: FPTM Results of the Trim \& Respond Static Pressure Reset Logic

\begin{tabular}{|c|c|c|}
\hline Event Description & $\begin{array}{c}\text { Time } \\
\text { Differential } \\
\text { from Start } \\
\text { (Minutes) }\end{array}$ & FPTM Value \\
\hline Read AHU duct static pressure (DSP) setpoint & +0 & 124.4 $\mathrm{Pa}\left(0.5 \mathrm{inH}_{2} \mathrm{O}\right)$ \\
\hline Read total air requests & +0 & 0 \\
\hline Read Zone 1 airflow setpoint & +0 & 47.2 L/s (100 cfm) \\
\hline Read Zone 2 airflow setpoint & +0 & $47.2 \mathrm{~L} / \mathrm{s}(100 \mathrm{cfm})$ \\
\hline Triple Zone 1 airflow setpoint & +0 & 141.6 L/s (300 cfm) \\
\hline Triple Zone 2 airflow setpoint & +0 & $141.6 \mathrm{~L} / \mathrm{s}(300 \mathrm{cfm})$ \\
\hline Read and verify increase in air requests & +2 & 5 \\
\hline $\begin{array}{l}\text { Confirm setpoint response }+15 \mathrm{~Pa} \\
\left(0.06 \mathrm{inH}_{2} \mathrm{O}\right) \text { at AHU }\end{array}$ & +2 & $140 \mathrm{~Pa}\left(0.5625 \mathrm{inH}_{2} \mathrm{O}\right)$ \\
\hline Double Zone 1 airflow setpoint & +2 & $283.2 \mathrm{~L} / \mathrm{s}(600 \mathrm{cfm})$ \\
\hline Double Zone 2 airflow setpoint & +2 & $283.2 \mathrm{~L} / \mathrm{s}(600 \mathrm{cfm})$ \\
\hline Read total air requests at AHU & +4 & 6 \\
\hline $\begin{array}{l}\text { Confirm setpoint response }+15 \mathrm{~Pa} \\
\left(0.06 \mathrm{inH}_{2} \mathrm{O}\right) \text { at AHU }\end{array}$ & +4 & $155.5 \mathrm{~Pa}\left(0.625 \mathrm{inH}_{2} \mathrm{O}\right)$ \\
\hline Double Zone 1 airflow setpoint & +4 & $566.3 \mathrm{~L} / \mathrm{s}(1200 \mathrm{cfm})$ \\
\hline Double Zone 2 airflow setpoint & +4 & $566.3 \mathrm{~L} / \mathrm{s}(1200 \mathrm{cfm})$ \\
\hline $\begin{array}{l}\text { Confirm setpoint response }+15 \mathrm{~Pa} \\
\left(0.06 \mathrm{inH}_{2} \mathrm{O}\right) \text { at AHU }\end{array}$ & +6 & $171.1 \mathrm{~Pa}\left(0.6875 \mathrm{inH}_{2} \mathrm{O}\right)$ \\
\hline Set Zone 1 airflow setpoint to min value & +6 & $47.2 \mathrm{~L} / \mathrm{s}(100 \mathrm{cfm})$ \\
\hline Set Zone 2 airflow setpoint to min value & +6 & $47.2 \mathrm{~L} / \mathrm{s}(100 \mathrm{cfm})$ \\
\hline Confirm no air requests at $\mathrm{AHU}$ & +8 & 0 \\
\hline $\begin{array}{l}\text { Confirm setpoint response }-12.4 \mathrm{~Pa} \\
\left(-.05 \mathrm{inH}_{2} \mathrm{O}\right) \text { at } \mathrm{AHU}\end{array}$ & +8 & $155.5 \mathrm{~Pa}\left(0.625 \mathrm{inH}_{2} \mathrm{O}\right)$ \\
\hline $\begin{array}{l}\text { Confirm setpoint response }-12.4 \mathrm{~Pa} \\
\left(-0.05 \mathrm{inH}_{2} \mathrm{O}\right) \text { at } \mathrm{AHU}\end{array}$ & +10 & $140 \mathrm{~Pa}\left(0.5625 \mathrm{inH}_{2} \mathrm{O}\right)$ \\
\hline $\begin{array}{l}\text { Confirm setpoint response }-12.4 \mathrm{~Pa} \\
\left(-0.05 \mathrm{inH}_{2} \mathrm{O}\right) \text { at AHU }\end{array}$ & +12 & 124.4 $\mathrm{Pa}\left(0.5 \mathrm{inH}_{2} \mathrm{O}\right)$ \\
\hline
\end{tabular}

This test simulated realistic system operation through adjusting individual zone airflow setpoints. The setpoints were increased in two zones to generate air requests, which were sent to the AHU. In response, the AHU duct static pressure setpoint was increased to meet the airflow demand. After the response was verified, the zone airflow setpoints were reduced to the minimum airflow to clear all air requests. As a result, the AHU trimmed the pressure setpoint every two minutes until it met the minimum value. 


\section{Implementation, Results and Observations}

The functional test scripts presented in this paper were created to evaluate compliance with the Guideline 36 high performance sequences. However, because the control logic that was selected as the test case was developed under RP-1455, the sequences of operation were not expected to have full compliance with the guideline. For example, the Guideline 36 specified freeze protection was not integrated into the control logic under test. From this compliance testing, there were several findings that proved the FPTM's capabilities as well as identified some limitations.

After initial tests, the AHU system did not respond to changes in the values of several BACnet objects as expected. A closer inspection of the AHU logic revealed the cause of the problem. The control logic had been developed to use some internal variables that were not coupled to the properties of the BACnet objects that should have been used. In effect, the results of the control actions were BACnet visible, but the inputs to the control logic were not. This problem was resolved by changing the control logic to use input values from associated BACnet objects. After this modification, the AHU system responded to the FPTM as expected. This problem illustrates that the way a control algorithm is developed can have a significant impact on the ability to test it or for an operator to override it if a problem develops.

In the Trim and Respond Static Pressure test, the duct static pressure setpoint both increased and decreased at a rate of $15.5 \mathrm{~Pa}\left(0.0625 \mathrm{inH}_{2} \mathrm{O}\right)$ per step, which is inconsistent with the ASHRAE standard trim and respond parameters of $-12.4 \mathrm{~Pa}$ and $14.9 \mathrm{~Pa}\left(-0.05 \mathrm{inH}_{2} \mathrm{O}\right.$ and $0.06 \mathrm{inH}_{2} \mathrm{O}$ ), respectively. Furthermore, for every extra pressure request, the respond value should increase, up to a maximum of $32.3 \mathrm{~Pa}\left(0.13 \mathrm{inH}_{2} \mathrm{O}\right)$. During the test, there were consistently four extra pressure requests, yet the pressure setpoint only responded to one extra request. Although the trim \& respond parameters were correctly entered in the implementation of the Guideline 36 control sequence, the logic may have a static internal value overriding them.

The Supply Air Temperature Control test is a prime example of the FPTM's utility. AHU systems are rarely required to adjust the supply air temperature by $8.3^{\circ} \mathrm{C}\left(15^{\circ} \mathrm{F}\right)$ within one hour. However, the FPTM replicated an extreme test case for AHUs meeting supply air setpoint changes. The ability to manipulate any variable of an HVAC system gives the user freedom to analyze extreme or faulty situations in real time, without risk of damaging physical components.

The Sum of Zones Airflow tests verified that the airflow leaving the AHU was consistent with the VAV box readings. In other words, the AHU airflow should approximately equal the sum of the six VAV box airflow readings. The results of this test were successful, as the six individual zone flows added together were within 1\% of the central AHU flow.

The Off-Mode Response test evaluated the supply fan response to occupied and unoccupied AHU modes. The AHU supply fan shall run when the system is in Occupied, Cool-down, or Setup mode. The supply fan shall also run in Setback or Warmup mode if there are VAV reheat boxes on perimeter zones, as is the case for the test configuration. When the AHU switches to unoccupied mode, the fan should not run. For this test the AHU was set sequentially to all modes and the start/stop value was read after a delay to account for the delay-on-break present in the logic. In unoccupied mode the supply fan start/stop was set to stop, while in all other 
modes it was set to start. However, the supply fan VFD setting was not set to zero in unoccupied mode. While the supply fan would not run due to the start/stop setting, a test which only looked at the VFD speed would not analyze this situation correctly.

The Setback and Setup modes are used during unoccupied periods to keep zone temperatures from straying too far from the occupied setpoints so that the system is able to achieve setpoint when initiated [3]. The Setback Mode test sets a single zone temperature $2.8^{\circ} \mathrm{C}\left(5^{\circ} \mathrm{F}\right)$ below the unoccupied heating setpoint while in unoccupied mode, causing the VAV box group to enter setback mode. The Setup Mode test sets a single zone temperature $2.8^{\circ} \mathrm{C}\left(5^{\circ} \mathrm{F}\right)$ above the unoccupied cooling setpoint while in unoccupied mode, causing the VAV box group mode to enter setup mode.

The Freeze Protection Setback Mode test activates the three stages of freeze protection as specified in Guideline 36. In this mode, the supply and return fans shut off, the outdoor air damper closes, the cooling coil opens to $100 \%$, the heating coil modulates, and two heating hot water plant requests are sent. The results of this test showed that the control logic failed to show the response prescribed in Guideline 36.

The third series of tests focused on evaluating the implementation of the fifteen AFDD conditions. For each fault condition shown in Table 1, a fault simulation method was developed to trigger the faults. Fault conditions 1 - 13 were successfully triggered from the test scripts, and the alarms were activated. The values used to trigger each fault condition were selected to confirm each fault condition's overall functionality. Scripts to test FC\#14 and FC\#15 were developed but were not tested. These fault conditions were added to Guideline 36 after RP-1455 was completed, and the control logic we tested did not include them.

\section{Conclusions and Next Steps}

The research described in this paper sought to validate HVAC-Cx commissioning software test scripts designed to assess compliance with the ASHRAE high performance sequences of operations for multiple-zone VAV AHUs. Control sequences implemented in RP-1455 were used as the test case. The HVAC-Cx tool was able to adjust various HVAC system variables and record the AHU response. The results were then evaluated to confirm that the controller responses were compliant with ASHRAE Guideline 36. The test results confirmed full compliance, with the important exceptions of elements where Guideline 36 had changed after RP-1455 was completed. The instances where test results identified that the control logic failed to show the response prescribed in Guideline 36 are valuable results. To complete the commissioning process, each of these non-compliant elements should be corrected.

Lessons learned include the importance of programmers being aware that decisions about the way in which they implement control sequences can impact the ability to run active tests. The active testing approach presented in this work relies on the ability to overwrite BACnet values in order to simulate the vast range of test conditions. The designs of future HVAC components should allow the user to easily modify variables to facilitate Cx. In the future, it may be beneficial to conduct a sensitivity study using the current AHU configuration to observe how each fault condition reacts to narrow tolerances. 
Additional next steps include testing other HVAC component sequences of operation using the FPTM and to partner with individuals who have developed control sequences using Guideline 36 and conducting further tests with the current AHU configuration.

\section{Acknowledgments}

The authors acknowledge the valuable work of the members of ASHRAE's Guideline Project Committee 36, the members of the RP-1455 Project Monitoring Subcommittee (Mike Pouchak, Chair; Barry Bridges, and Gaylen Atkinson) and the RP-1455 Principle Investigator. The authors also acknowledge the value of the Functional Testing Guide [8], which provided one of the first publicly-available resources for developing functional tests and informed this work.

\section{References}

[1] Hydeman et al. 2015. RP-1455 and Guideline 36: Control Sequences \& Controller Programming. ASHRAE Journal March.

[2] Milesi Ferretti, N., D. Shipley, W. Zalis, and S. Bushby. 2014b. "Roadmap for Building Commissioning Research Workshop Summary Report”. NIST TN 1849, National Institute of Standards and Technology.

[3] American Society of Heating, Refrigerating and Air Conditioning Engineers 2018. Guideline 36-2018 High Performance Sequences of Operation for HVAC Systems. Atlanta, GA. Atlanta, GA. https://www.techstreet.com/ashrae/standards/guideline-36-2018-highperformance-sequences-of-operation-for-hvac-systems?product id=2016214

[4] Hydeman et al. 2014. Final Report ASHRAE RP-1455 Advanced Control Sequences for HVAC Systems, Phase I, Jan. 14, 2014.

[5] Schein, J., Bushby, S.T., Castro, N.S. 2006. “A Rule-Based Fault Detection Method for Air Handling Units,” Energy \& Buildings Vol. 38, Issue 12, December 2006, pp. 14851492.

[6] American Society of Heating, Refrigerating and Air Conditioning Engineers RP-1711, "Advanced Sequences of Operation for HVAC Systems- Phase II Central Plants and Hydronic Systems"

[7] Seattle City Light. The Building Commissioning Assistance Handbook http://www.seattle.gov/light/conserve/business/bdgcoma/cv6_bcam.htm

[8] Portland Energy Conservation Inc. 2008. Functional Testing Guide: from the Fundamentals to the Field, http://www.ftguide.org/ftg/SystemModules/AirHandlers/Functional Testing for Air Handlers.htm

[9] Milesi Ferretti, N, M.A. Galler. 2015. Users Guide to HVAC-Cx v2.2. NIST TN 1981. NIST TN 1849, National Institute of Standards and Technology.

[10] Bushby, Steven T., et al., 2009, “The Virtual Cybernetic Building Testbed- A Building Emulator,” ASHRAE Transactions, Volume 116, Part 1, p37.

[11] Milesi Ferretti, Natascha S., et al., 2018. Retro-Commissioning a Performing Arts Center using HVAC-Cx. National Institute of Standards and Technology. Pending Publication.

[12] Milesi Ferretti, N, M.A. Galler. 2018. HVAC-Cx Building HVAC Systems Commissioning Tool: Functional Test Scripts. https://www.nist.gov/servicesresources/software/hvac-cx-building-hvac-systems-commissioning-tool 


\section{Appendix A: Multiple Zone VAV AHU Test Scripts for Normal Operation}

Ten test scripts were developed to evaluate compliance with Guideline 36 under normal operating conditions. The test scripts, their associated Guideline section number, and the test script filenames are listed in Table A1. The test scripts can be obtained from the NIST HVAC-Cx website [12].

Table A1: Listing of Function Performance Test Scripts

\begin{tabular}{|c|c|c|}
\hline $\begin{array}{c}\text { Functional } \\
\text { Performance } \\
\text { Test }\end{array}$ & $\begin{array}{l}\text { GPC } 36 \\
\text { Section }\end{array}$ & Description \\
\hline $\begin{array}{l}\text { Zone Air } \\
\text { Temperature } \\
\text { Reset Test }\end{array}$ & 5.6.8.1 & $\begin{array}{l}\text { This test modified the zone temperature setpoint for one } \\
\text { zone to verify the number of cool requests was modified. } \\
\text { Does not read from AHU or Group Manager. } \\
\text { File: CoolingSATreset_request.xml }\end{array}$ \\
\hline $\begin{array}{l}\text { Supply Air } \\
\text { Temperature } \\
\text { Control Test }\end{array}$ & 5.16 .2 & $\begin{array}{l}\text { Modifies SATsp and verifies SAT continues to track } \\
\text { SATsp. } \\
\text { File: SAT setpoint change response text.xml }\end{array}$ \\
\hline $\begin{array}{l}\text { Trim \& Respond } \\
\text { Parameter Test }\end{array}$ & 5.16 .1 .2 & $\begin{array}{l}\text { Reads trim \& respond parameters for pressure control to } \\
\text { confirm compliance with guideline. } \\
\text { File: Confirm Trim \& Respond parameters.xml }\end{array}$ \\
\hline $\begin{array}{l}\text { Trim \& Respond } \\
\text { Temperature Test }\end{array}$ & 5.16 .2 .2 & $\begin{array}{l}\text { Test trim \& respond by raising zone temperature sensors, } \\
\text { creating reset requests. Reads reset requests after delay to } \\
\text { verify proper operation of trim \& respons logic. } \\
\text { File: Evaluate Trim \& Respond Tmin.xml }\end{array}$ \\
\hline $\begin{array}{l}\text { Trim \& Respond } \\
\text { Static Pressure } \\
\text { Test }\end{array}$ & 5.16 .1 .3 & $\begin{array}{l}\text { Modifies flow setpoints on two terminal units to force } \\
\text { response from AHU trim \& respond logic. } \\
\text { File: Trim \& Respond Pressure Test.xml }\end{array}$ \\
\hline $\begin{array}{l}\text { Sum of Zones } \\
\text { Airflow Test }\end{array}$ & N/A & $\begin{array}{l}\text { Reads the airflow from each of the zones, and from the } \\
\text { AHU. User must sum airflow from the zones and } \\
\text { compare with airflow from the AHU. } \\
\text { File: Sum_of Zone_airflow test.xml }\end{array}$ \\
\hline $\begin{array}{l}\text { Off Mode } \\
\text { Response Test }\end{array}$ & 5.16 .1 .1 & $\begin{array}{l}\text { Verifies that the Supply Air Fan is on or off as } \\
\text { appropriate in each operational mode of the AHU. } \\
\text { File: Off Mode Response Test.xml }\end{array}$ \\
\hline $\begin{array}{l}\text { Setback Mode } \\
\text { Test }\end{array}$ & 5.4.6.4 & $\begin{array}{l}\text { Adjusts zone temperatures to force AHU to switch from } \\
\text { File: Unoccupied mode to Setback mode. }\end{array}$ \\
\hline Setup Mode Test & 5.4.6.6 & $\begin{array}{l}\text { Adjusts zone temperatures to force AHU to switch from } \\
\text { File: Unoccupied mode to Setup mode.xml }\end{array}$ \\
\hline $\begin{array}{l}\text { Freeze Protection } \\
\text { Test }\end{array}$ & 5.16 .12 & $\begin{array}{l}\text { Adjusts SAT to test all stages of freeze protection. } \\
\text { File: Freeze protection mode response test sat.xml }\end{array}$ \\
\hline
\end{tabular}




\section{Appendix B: Multiple Zone VAV AHU Test Scripts for Fault Conditions}

Fifteen test scripts were developed to evaluate compliance with Guideline 36 under fault conditions. The fault conditions are described in Guideline 36 Section 5.16.14.7 [3] and summarized in Table 1 of this report, together with the fault simulation method used. The test scripts can be obtained from the NIST HVAC-Cx website [12]. 
Appendix C: Use Case \#1 Supply Air Temperature Control Test for VAV AHUs Event Script File

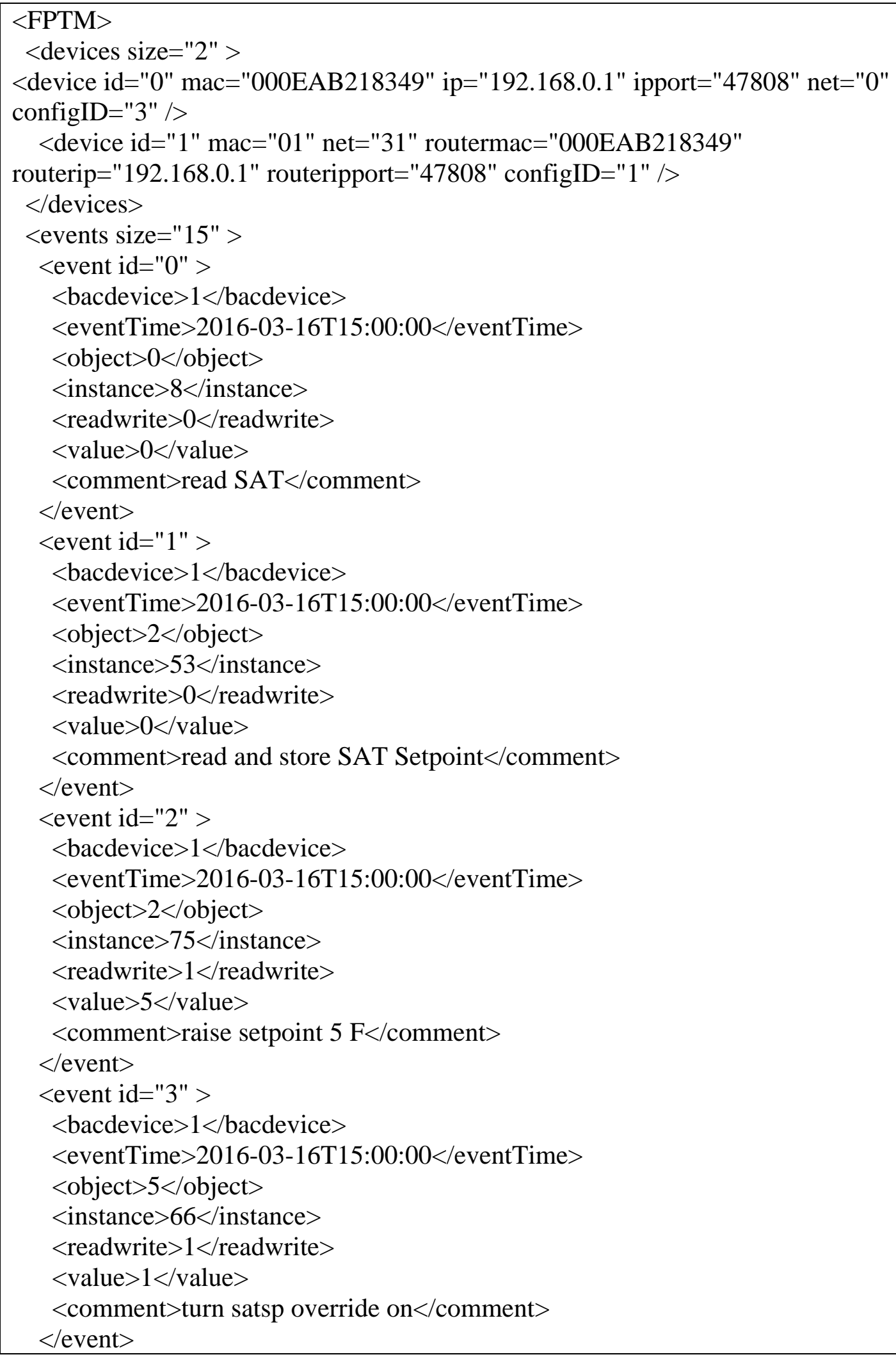




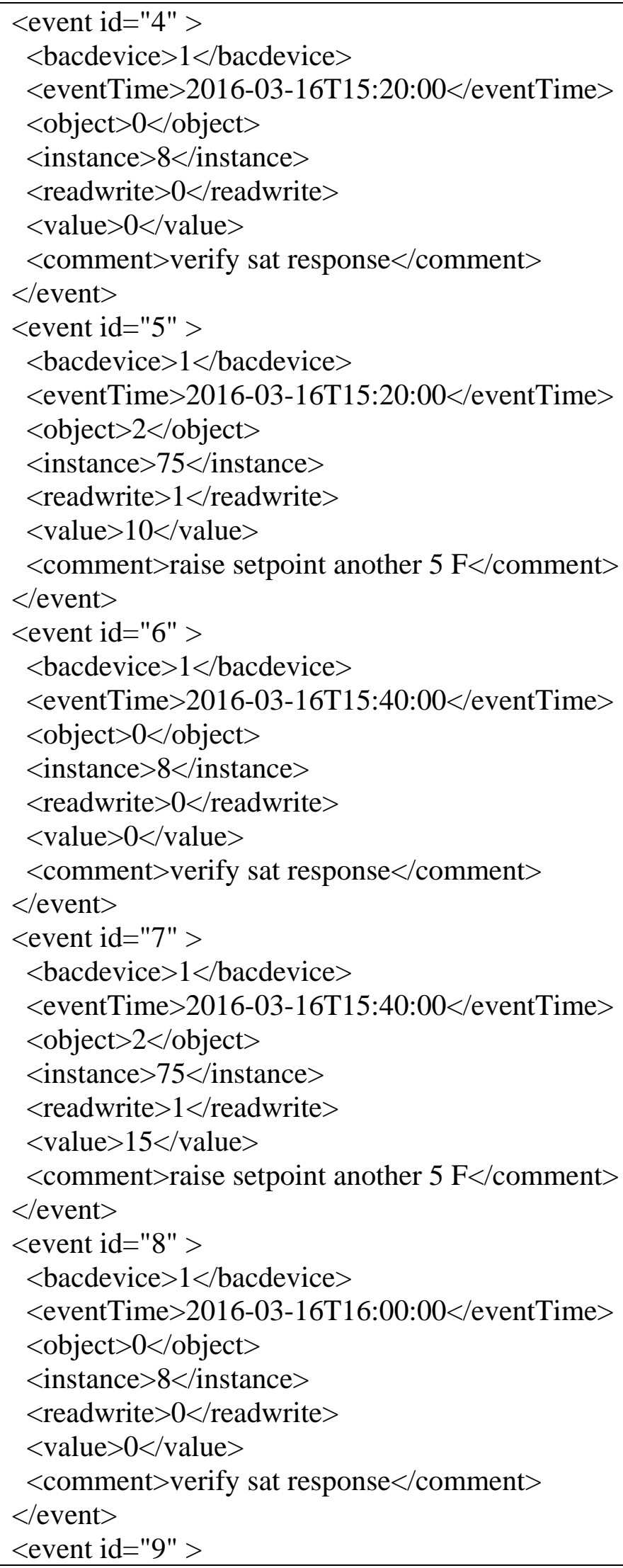




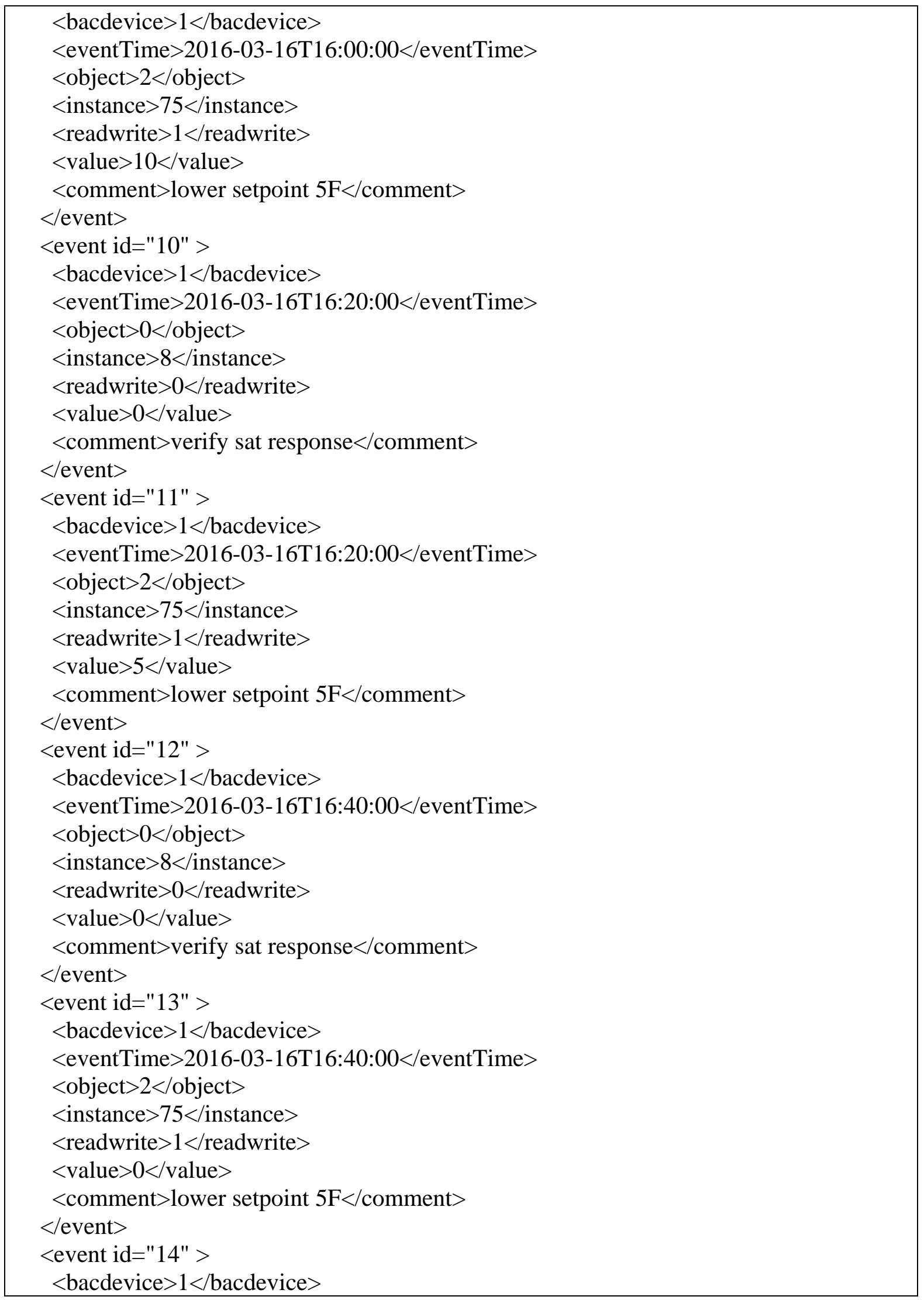




\section{Appendix D: Use Case \#2 Trim \& Respond Static Pressure Reset Logic for VAV AHUs Event Script File}

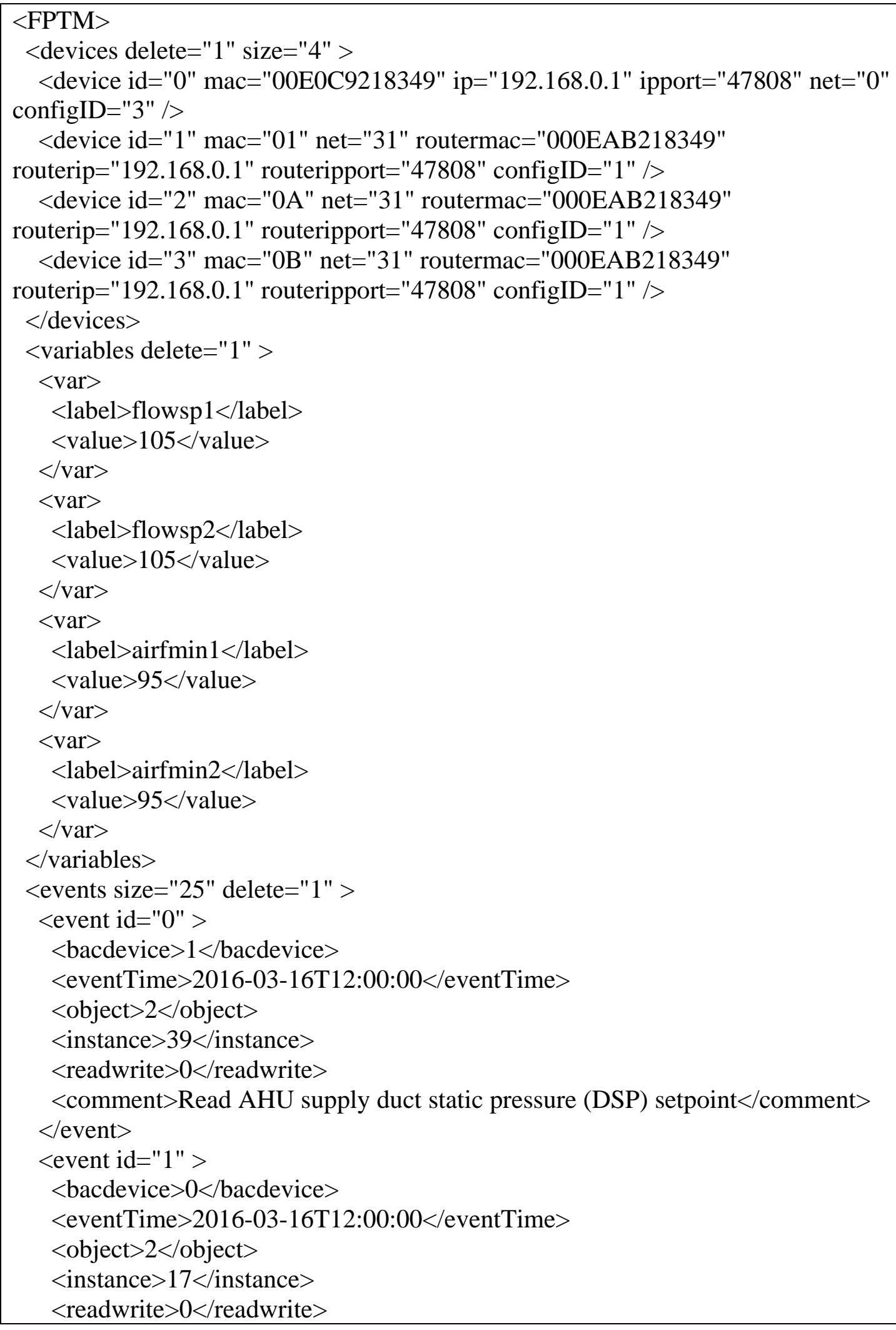




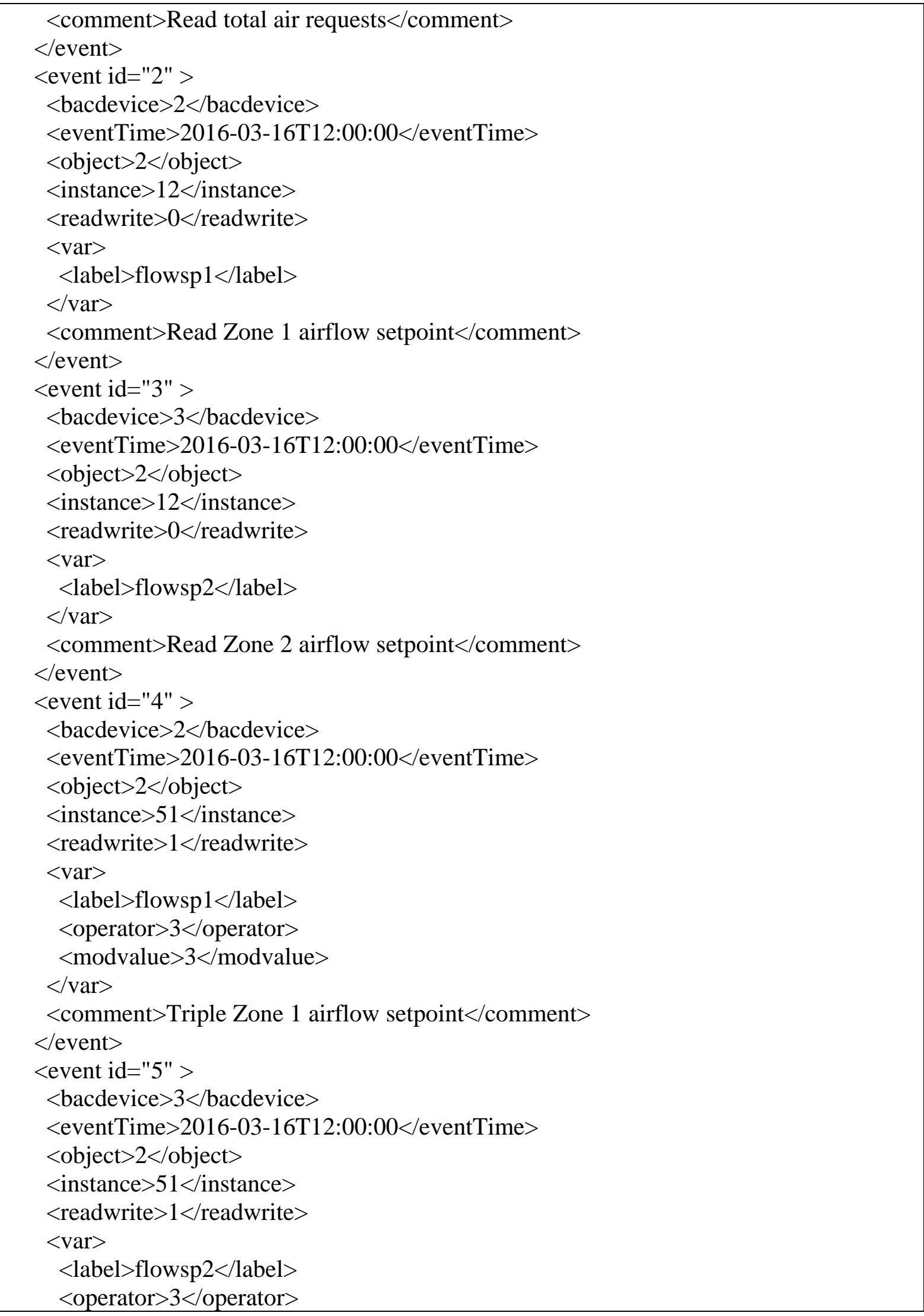




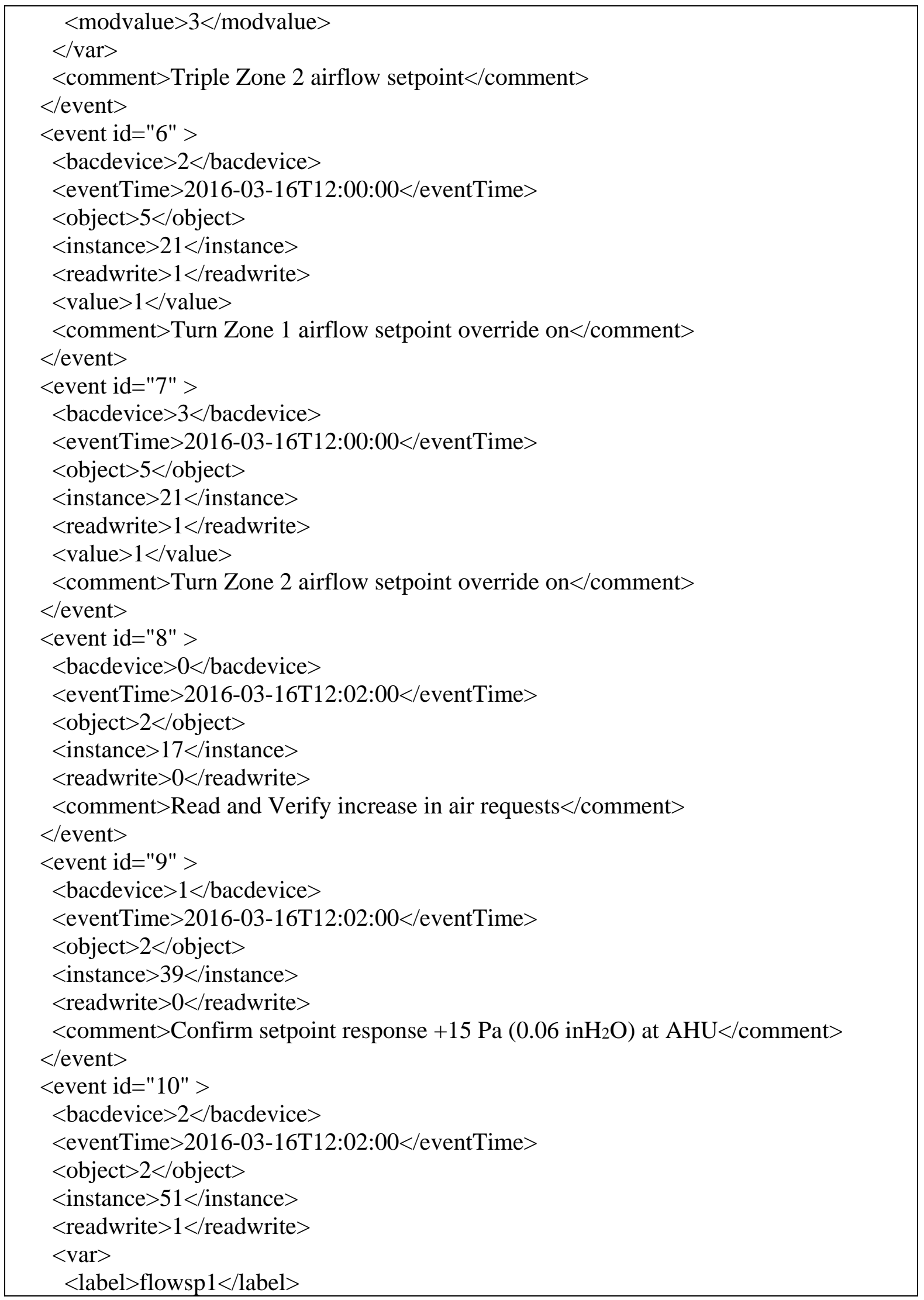




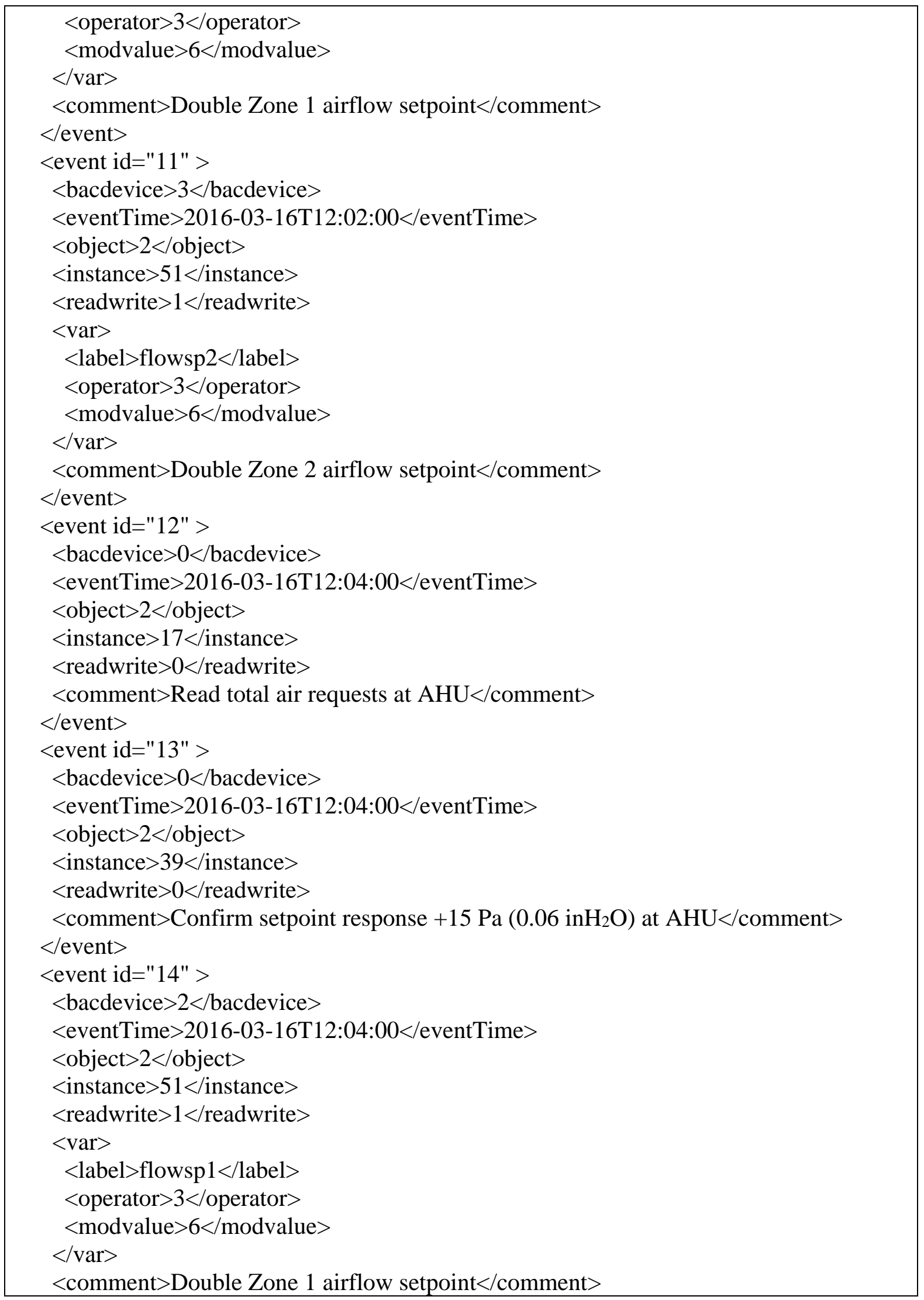




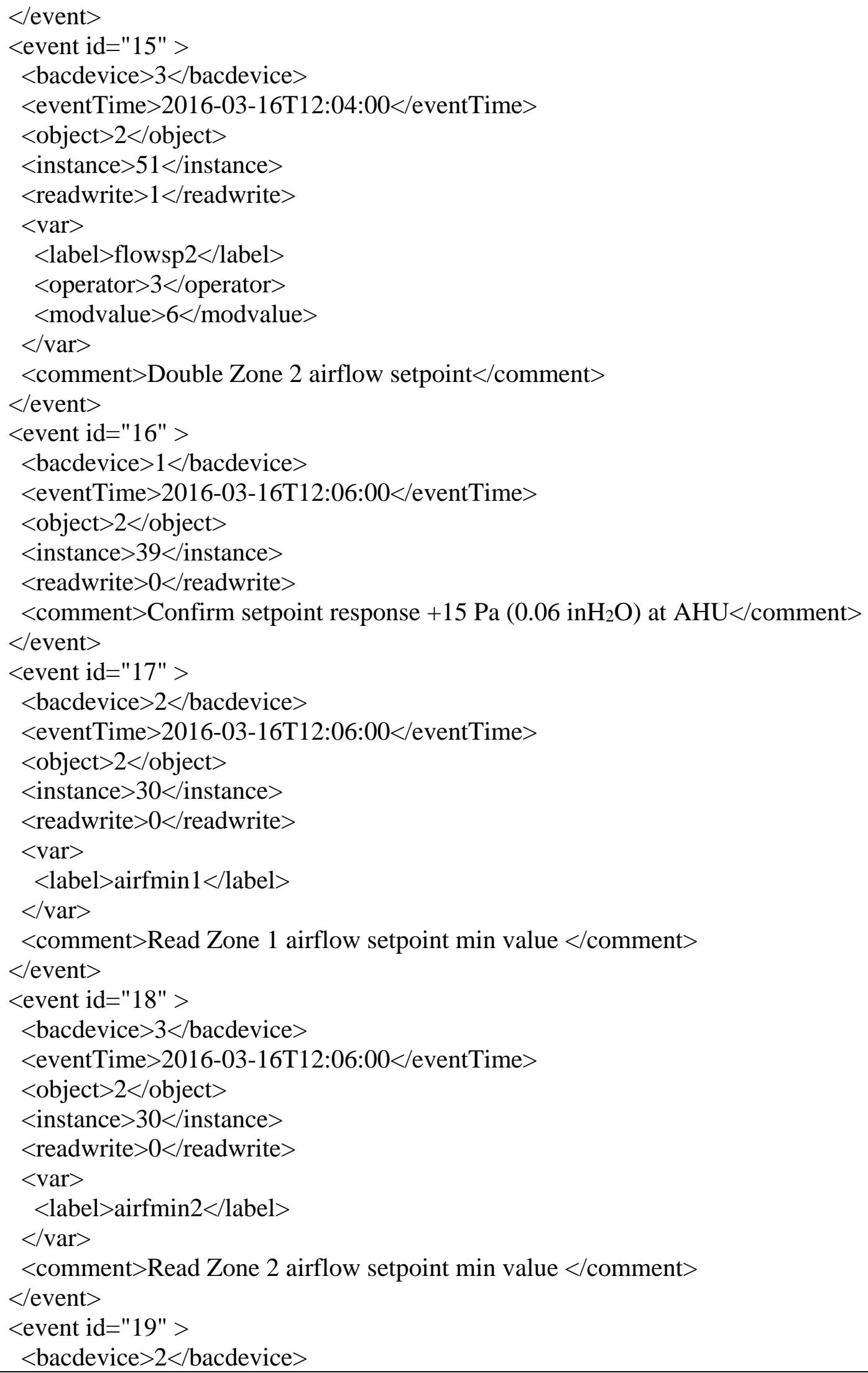




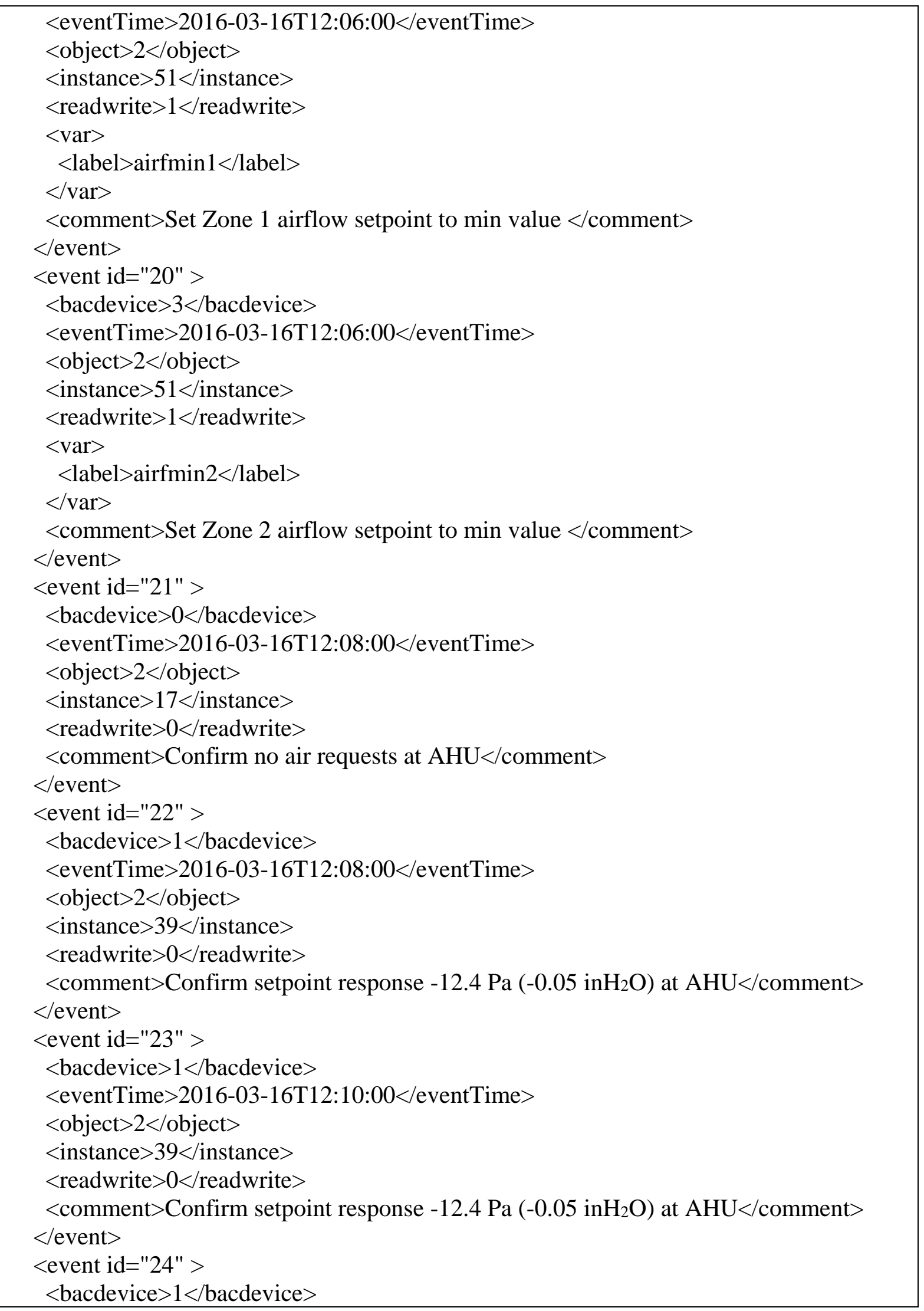




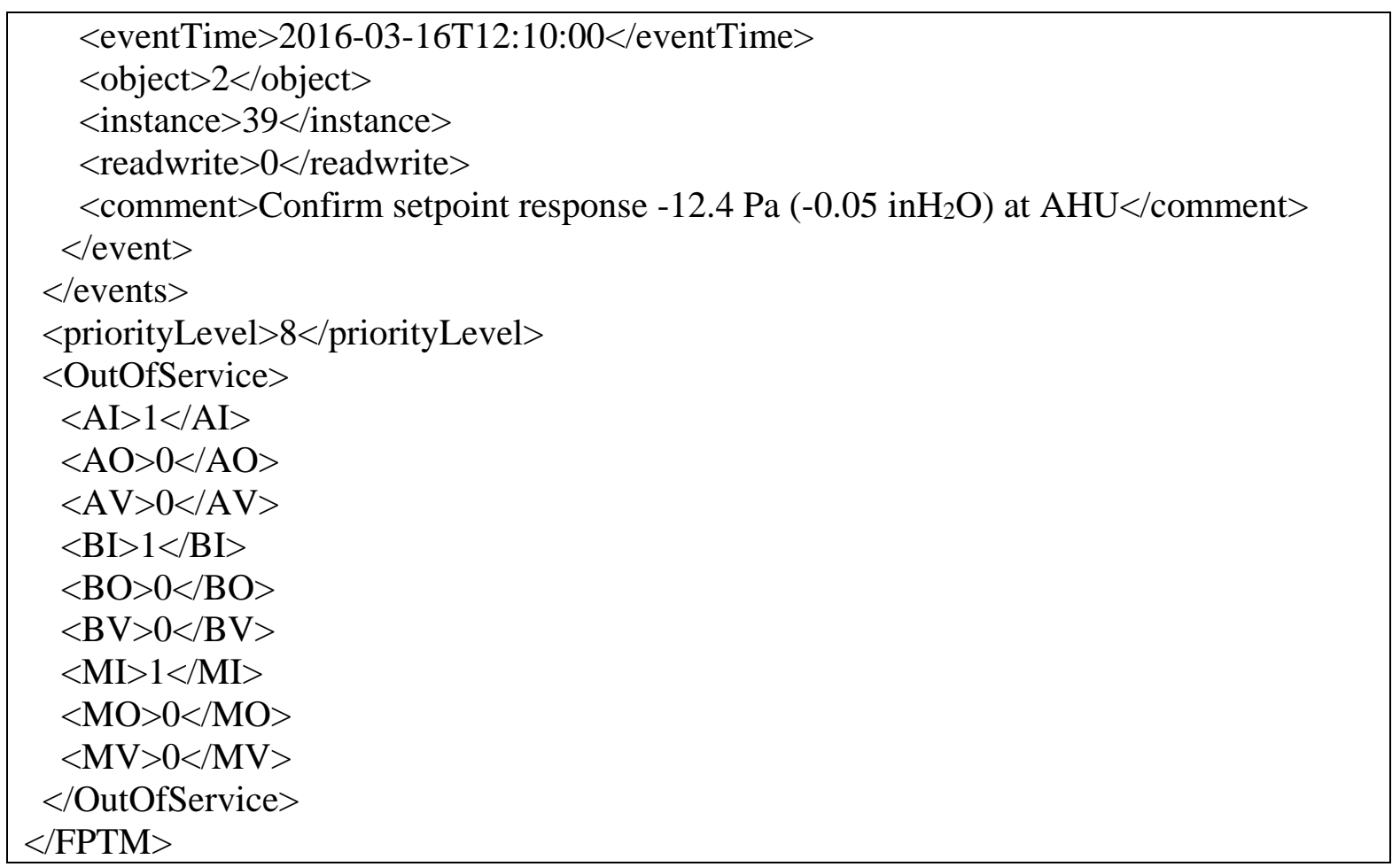

